\title{
"I'm Thinking I Want to Live a Better Life": Syrian Refugee Student Adjustment in New Brunswick
}

\author{
Helen Massfeller \\ University of New Brunswick \\ helen.massfeller@unb.ca \\ Lyle Hamm \\ University of New Brunswick \\ lhamm@unb.ca
}

\begin{abstract}
In this paper, the authors explore the re-adjustment experiences of seven refugee students from Syria and Iraq, who enrolled in a large high school in New Brunswick. Data were collected through semi-structured interviews, school and community documents, and field notes. Five themes were identified and are reported and discussed in this paper. Recommendations for future direction regarding how to successfully integrate Syrian refugee children into Canadian schools are provided.
\end{abstract}

\section{Context of the Study}

The province of New Brunswick is trying to grow and stabilize its shrinking population through economic and immigration strategies (Bascaramurty, 2017; New Brunswick Government, 2014; 2016). There was a gradual increase in the number of newcomer families arriving in our province over the past decade. Many newcomer parents have found work in long-haul trucking, agriculture, aquaculture, and service-based industries (New Brunswick Multicultural Council, 2016). Since 2015, there has been a sharp rise in refugee families arriving in New Brunswick from war-torn nations, the largest influx being from Syria (Guterres, 2015; Huras, 2016). In fact, it is now estimated that over 40,000 Syrian refugees have settled in Canada since war broke out in their country in 2011 (Government of Canada, 2018). It has been reported that there will be more Syrian families arriving in Canada in the future (Chilibeck, 2018; Perreaux, 2017). To date, over 1,500 Syrians now consider New Brunswick their new home, and it is expected that more newcomer families will be enticed to come to New Brunswick as a result of the province's population growth and economic growth strategies (New Brunswick Multicultural Council, 2016). One strategic focus the current government has implemented is the "Development of firm-specific immigration plans for larger businesses that need a significant number of workers" (New Brunswick Government, 2016, p. 14). This current reality has impacted New Brunswick schools, and as of September, 2017, there were 650 Syrian students in our public educational institutions (Bissett, 2017). Even with the government's employment strategies, one of the biggest challenges facing New Brunswick is job security for new immigrant families. If the Syrian newcomers do not find work, many will leave for larger centers in other provinces where there are economic opportunities, and their children will thus experience further interruptions in their schooling (Hamm, Massfeller, Hamm, Oulette \& Damoah, 2017).

Journal of Contemporary Issues in Education, 2019, 14(1), pp. 33-54.

ISSN 1718-4770 (c) Author(s), Creative Commons Attribution 4.0 (CC BY 4.0) licence

http://ejournals.library.ualberta.ca/index.php/JCIE 
To date, there have been a few studies in New Brunswick that examine diversity, demographic changes, and refugee student settlement and integration in communities and schools (Peck, Sears \& Donaldson, 2008; Varma-Joshi, Baker \& Tanaka, 2004; Wilson-Forsberg, 2012; 2016). This paper will report findings from our case study research in Eastern Coastal High School (ECHS, a pseudonym) in New Brunswick. ECHS has been one of many provincial schools to welcome hundreds of international, new immigrant and refugee students the past decade.

\section{Literature Review}

Children fleeing war-torn countries often experience violence, torture, persecution, profound multiple losses, exploitation, and ongoing instability that can impact their mental health and psychological well-being (Hassan et al, 2016). Refugee children arrive in classrooms with significant histories of trauma, educational gaps in learning, interpersonal issues, and difficulty trusting strangers, particularly authority figures (McDonald, 2000; Pryor, 2001; Smith-Davis, 2004). Many of these children become marginalized and lonely, and they feel trapped between their cultures and the dominant culture in their new school. The feelings of loneliness and alienation felt by many students new to Canada and North America have been documented extensively in the research literature on immigrant and refugee student arrival and adjustment in schools (Coelho, 1998; Gunderson, 2000; Kelly, 1998; Kirova, 2001; Pardhan, 1998). Research specific to the complex needs of the Syrian refugee students is emerging. For this paper, we draw from the broader area of research on newcomer children including immigrant children, with specific focus on these children in Canada and New Brunswick. Syrian children may experience a wide range of mental health problems including exacerbations of pre-existing mental disorders or new problems due to conflict related violence and displacement that occurred prior to their arrival (Hassan et al., 2016; Sirin \& Rogers-Sirin, 2015) in New Brunswick. Some of the presenting mental health issues may include anxiety, sleep issues (Montgomery \& Foldspang, 2005), and behavioral problems (Henley \& Robinson, 2011). The most common mental health problems of children exposed to war and violence are Post Traumatic Stress Disorder (PTSD) and depression (Baddoura \& Merhi, 2015; Ghumman, McCord \& Chang, 2016).

However, these children also demonstrate resilience, strength, and the ability to adapt quickly to new environments (Rousseau, Drapeau \& Rahimi, 2003; Stewart, 2017a, 2017b; Ungar, 2013). A number of factors leading to successful adaptation to the new context include appropriate assessment and placement, mental health needs of learners, and the social-emotional impacts of discrimination, bias, prejudice, or racism (Hassan et al., 2016; Vega, Lasser \& Plotts, 2015).

\section{The School Context}

Ongoing demographic change and increasing diversity can bring a host of additional social challenges and educational complexities to the school context. Syrian children struggle to adapt to life as refugees in a foreign country due to feelings of estrangement, loss of identity, and yearning to go home (Moussa, 2014). Stress and social isolation is exacerbated by social tensions and discrimination against refugees (Boswall \& Al Akash, 2015). A culturally safe environment

Journal of Contemporary Issues in Education, 2019, 14(1), pp. 33-54.

ISSN 1718-4770 (c) Author(s), Creative Commons Attribution 4.0 (CC BY 4.0) licence http://ejournals.library.ualberta.ca/index.php/JCIE 
is an important prerequisite to building trust and collaboration and fostering mutual respect (Hassan et al., 2016).

Research conducted in New Brunswick schools found that many Anglophone students demonstrate limited understandings of ethnic diversity (Hamm, Peck \& Sears, 2018; Peck, Sears \& Donaldson, 2008). Often students in the dominant culture do not recognize cultural and religious symbols that have significance to newcomer and refugee students. Wilson-Forsberg (2012) found that the new immigrant students in two New Brunswick schools needed to feel and experience an immediate sense of identity and belonging to their school and community. The author later reported that Canadian students in the schools took initiative and intentionally engaged their newcomer peers and brought them into school activities for social and democratic participation (Wilson-Forsberg, 2016). This connection acts as a moderating factor on the risk of prearrival trauma on depressive symptoms (Beiser, Turner \& Ganesan, 1989; Hadfield, Ostrowski \& Ungar, 2017). Wilson-Forsberg (2016) further argued that the students needed multiple school personnel - teachers, administrators, support staff, and especially their Canadian student peers - to intentionally include them in classroom, extra-curricular, and social activities.

School leaders and teachers must proactively learn about what countries the children and their families will be arriving from. This knowledge helps educators transition students smoothly into the school and can reduce stress and anxiety (McCray, Wright \& Beachum, 2004; Ryan, 2003; Shields, 2003; Walker \& Dimmock, 2005). School leaders must set priorities and construct strategies to address the most pressing challenges they will face when the children and their families arrive (Sather \& Henze, 2001; Soukamneuth, 2004). Building on this notion, school personnel such as guidance counsellors and school psychologists play a pivotal role in the professional response to the large influx of newcomers and refugees in demographically changing schools (Cooper, 2009; Vega, Lasser and Plotts, 2015). These mental health professionals have the multicultural competencies to work effectively with refugee children and enhance their academic outcomes, as well as to support teachers who are struggling to construct effective pedagogies and welcoming classrooms for their new immigrant and refugee students.

\section{The Curriculum and Refugee Children}

Many researchers have argued that educators are often slow to adapt their pedagogies and curriculums for newcomer and refugee students (Evans, 2007; Grady, 2001; Howard 2007). Arnett (2014) found that new immigrant students in New Brunswick between the ages of 18-21 found their courses and curriculum challenging due to their level of English language competency. Arnett (2014) reported that the federal government was making a more concerted effort in investing in K-12 language programming than for young adults aged 18-21 due to the New Brunswick Inclusive Education Policy (Porter \& AuCoin, 2012). The researcher argued that it is critically important to provide resources for older new immigrant youth so they can transition successfully out of high school into higher education and jobs.

Further, it is important for educators in diverse and demographically-changing schools to examine their curriculums constantly to ensure issues like racism and discrimination are challenged in classroom discourse, and students are provided learning activities to grow their

Journal of Contemporary Issues in Education, 2019, 14(1), pp. 33-54.

ISSN 1718-4770 (c) Author(s), Creative Commons Attribution 4.0 (CC BY 4.0) licence

http://ejournals.library.ualberta.ca/index.php/JCIE 
knowledge (Bolgatz, 2005; Delpit, 2006; Gay, 2010). Walker and Dimmock (2005) suggested that principals encourage staff members to infuse learning activities about cultural diversity to counter racism and other forms of discrimination in their classes. Inevitably, teachers in diverse and demographically changing schools encounter multiple and diverse challenges working with new immigrant and refugee students (Hamm \& Cormier, 2015). It may be imperative for teachers and leaders to work together creatively and seek educational and social opportunities for all students who share common spaces (Banks, et al. 2005; Skidmore, 2016). For these reasons, we draw from critical pedagogy (Ghosh \& Abdi, 2013) as the theoretical framework to guide us in our work for this project. Kincheloe (2005) stated that, "Critical pedagogy is interested in the margins of society, the experiences and needs of individuals faced with oppression and marginalization ... Critical pedagogy, thus, amplifies the voices of those who have had to struggle to be heard" (p. 23). Schools in Canada provide opportunities and social spaces for educators and students to work together to unpack and understand the ideas of equity, equality and social justice (Solomon, Levine-Rasky \& Singer, 2003). Our project has provided us an opportunity to give voice to and learn with several refugee students at ECHS who shared their stories of struggle and, most importantly, their stories of hope for a better future.

\section{Methodology}

In our qualitative case study research (Stake, 1995; 2000), we were guided by constructivist philosophy that assumes there are multiple realities and perceptions operating in schools amongst all the social actors that teach, learn, and lead in them. We chose to work reciprocally with our participants to help us better understand their experiences in their previous homelands, the countries they escaped to with their families, and their social and academic adjustment in New Brunswick after 2016. Early in our study in 2015, we surveyed and interviewed school administrators and educators and conducted three focus group sessions to gather our data sets. It was our hope that building reciprocal professional relationships with the ECHS staff and then the students would allow us to engage with more participants. In early 2016, when we were about to recruit newcomer student participants, ECHS had an influx of Syrian refugee students. Working closely with the administration team, we decided to pull back from our inquiry to allow the educators and administrators time to welcome and integrate 57 Syrian students into their school community and culture. When we returned several months later, the students had become more comfortable and secure in their new environment. In total, we interviewed seven (7) newcomer refugee students. Six of the student participants (SP2, SP4, SP5, SP6, SP7, and SP8) were from Syria and had arrived in Canada in 2016. The table below indicates where the students were from (Syria) and in italics, the country they escaped to (i.e. SP2 escaped to Jordan) before they and their families left for Canada. One student (SP1) was born and lived in Iraq but escaped with his family to Syria during the second Iraq war in 2003. The student later escaped to Canada when the Syrian conflict broke out in 2011. The main research question guiding our inquiry in our case study is: What is/are the impact and implications of immigration, demographic changes and increasing diversity on teachers, administrators and students in a New Brunswick high school context? For this paper, the research question is: How are Syrian refugee students adjusting in their New Brunswick high school and community?

Journal of Contemporary Issues in Education, 2019, 14(1), pp. 33-54.

ISSN 1718-4770 (c) Author(s), Creative Commons Attribution 4.0 (CC BY 4.0) licence http://ejournals.library.ualberta.ca/index.php/JCIE 


\section{Participants}

All student participants were given descriptive identifying codes to provide anonymity and allow us to clearly communicate their narratives. For instance, in the Table below, NB SP1 means New Brunswick Student Participant One. The student matrix is represented in the diagram below:

\begin{tabular}{|c|c|c|c|}
\hline Student & $\begin{array}{l}\text { Gender, Age, and time } \\
\text { in New Brunswick }\end{array}$ & $\begin{array}{l}\text { Country settled prior to } \\
\text { arriving in Canada }\end{array}$ & Interview date \\
\hline NB SP1 & Male, 19,5 years & Iraq and Syria & May 4, 2017 \\
\hline NB SP2 & Female, 17,1 year & Syria and Jordan & June 1, 2017 \\
\hline NB SP4 & Male, $\mathbf{1 5}, 9$ months & Syria and Jordan & May 312017 \\
\hline NB SP5 & Female, 15, 4 months & Syria and Jordan & May 312017 \\
\hline NB SP6 & Male, 17,5 months & Syria and Turkey & May 302017 \\
\hline NB SP7 & Male, $\mathbf{1 5}, 5$ months & Syria and Turkey & May 232017 \\
\hline NB SP8 & Female, $\mathbf{1 8}, 1$ year & Syria and Lebanon & June 12017 \\
\hline
\end{tabular}

\section{Data Collection and Analysis}

With the support of the students' English as an Additional Language (EAL) teachers, we were able to initially meet and speak about our project with 49 students and invite their participation. Seven students accepted our invitation and had their parents provide their consent. We were told by the EAL teachers who supported our project that many more students wanted to participate, but they were not confident in their English language skills at the time of our inquiry. One student who did not participate was visibly suspicious that his sibling was participating in an interview. We were able to speak with him about the study and reassure him of our educational objectives in speaking with the students. He then seemed more at ease with our presence in the school and our work with his sibling. Each interview was conducted in English and lasted between 40 minutes and one hour. Some students struggled during their interviews because they had only been learning English for a few months. We did not wish to use the services of a translator because we believed the presence of another person in the room might be disruptive for the students and us. We were pleased with how well the students engaged us and did their best to respond to our questions during their interviews.

Additional data was used for this study, including field notes $(\mathrm{N}=113$ pages $)$, school and community documents, and relevant news articles and editorial cartoons from local, provincial, national, and international news sources $(\mathrm{N}=162)$. The latter data source was very important to the project as several of these news articles highlighted many of the challenges the Syrian families had in New Brunswick. Some of these stories reported the challenges newcomers confronted with housing (Llewellyn, 2015), employment (Huras, 2016), and racism and discrimination (Blanch, 2017).

We collected and coded the interview data and provided our individual and group interpretations on the running record of "data events" (Hamm, Scott \& Massfeller, 2015). Drawing from grounded theory methodology, we followed the constant comparative analytical process (Fram, 2013) to form themes from our data. The data were organized into categories, and eventually we viewed emerging patterns that we constructed into themes. The diagram that follows illustrates the five key thematic findings in our study that involved the new Canadian Syrian students.

Journal of Contemporary Issues in Education, 2019, 14(1), pp. 33-54.

ISSN 1718-4770 (c) Author(s), Creative Commons Attribution 4.0 (CC BY 4.0) licence http://ejournals.library.ualberta.ca/index.php/JCIE 


\section{The Students told us ...}

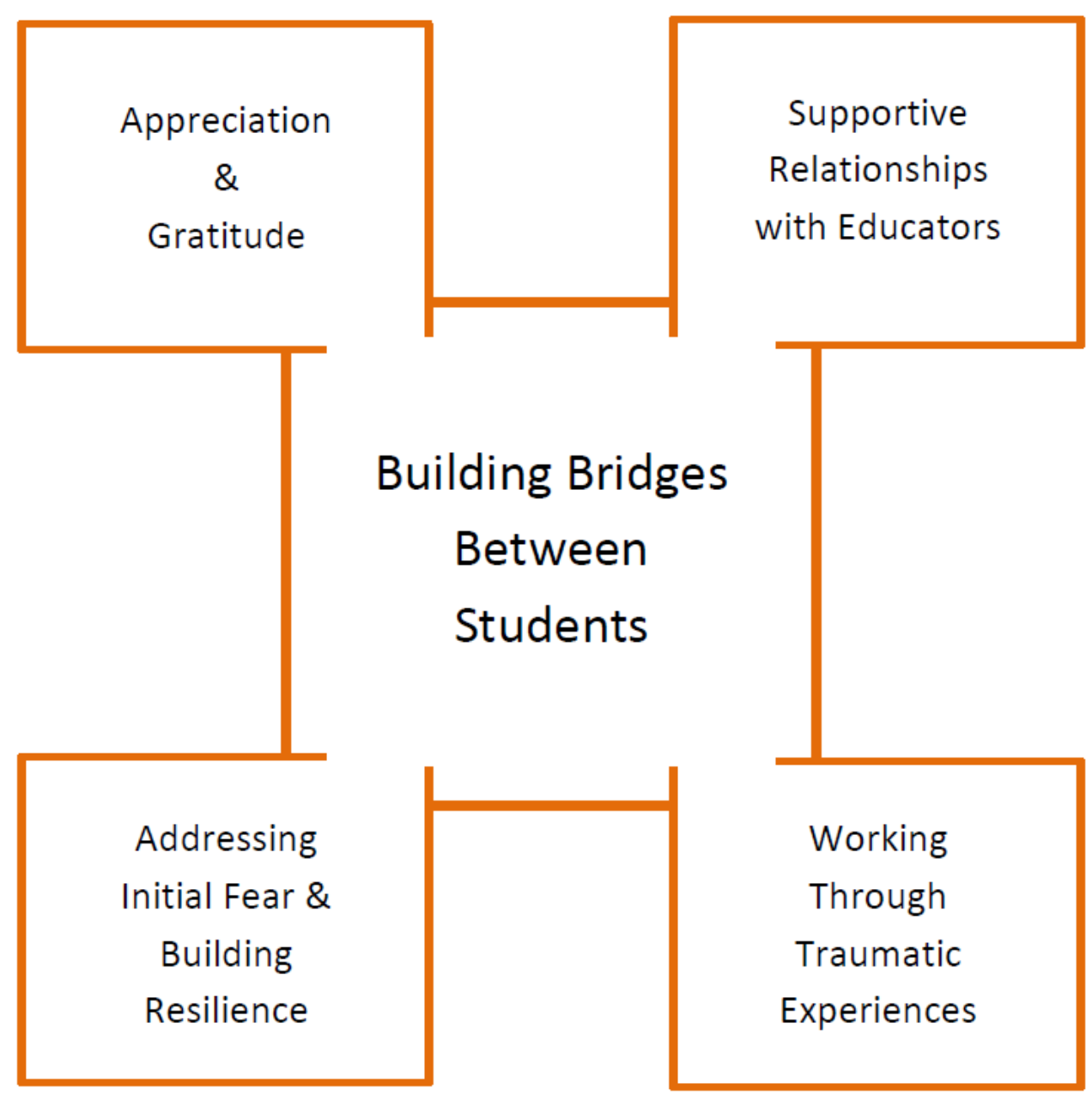

(C) L. A. Hamm 2017

\section{Changing Our Language From New Immigrant and Refugee Student(s) to New Canadian Student(s) \\ During the student interviews, we asked each student participant how they felt about being called a new Canadian rather than being referred to as a refugee or newcomer student. We asked this question deliberately as we have been motivated and encouraged throughout our inquiry to reflect upon and change our own language in framing newcomer/refugee/new}


immigrant/temporary foreign Canadian children. We have witnessed mounting stories of racism and discrimination through damaging news reports (Blanch, 2017), and we have observed firsthand in our field work the challenges that many new Canadian students and their families have experienced integrating into Canadian society. We believe the more quickly students see themselves as 'new Canadians' as opposed to the marginalizing language of 'refugees', they may gain a greater sense of belonging within their schools, communities, and in our Canadian society (Gourley, 2016; Hamm, Peck \& Sears, in press). All the students we interviewed appreciated being referred to as new Canadians.

\section{Findings}

\section{Theme 1 - Building Bridges Between Students}

We learned early in the case study through our work with ECHS educators and administrators that their new Canadian students were struggling to make friends within the dominant Canadian Anglophone population (Hamm, Oulette \& Hamm, 2017; Hamm, Massfeller, Hamm, Oulette \& Damoah, 2017). We believed this theme to be a core finding in this part of our case study at ECHS because the educators had expressed their concerns about the nature of the relationships between the new Canadian students and the Canadian-born students in the school. When opportunities arose in the interviews with our student participants to discuss their levels of authentic engagement with their Canadian peers, we inquired deeply. Over and over, the students expressed their deep desire to be part of school social groups, which was difficult for them because they lacked confidence, were shy, and struggled to speak English coherently. Two students told us:

I want (a) friend, (a) Canadian ... And when I go to them, I'm shy a little bit. I like Canadians and Syrians together. (NB SP7)

I want to learn English, I want ... a friend Canadian. I want friend(s) in Canadian, but I don't speak English ... I know (the) cafeteria, but I just sit. Just me. Because I don't have (a) friend ... Canadian. I want Canadian friends. (NB SP6)

One Syrian student described how she had made a Canadian friend and what that friendship did for her confidence, sense of belonging, and academic achievement. She said,

I met her last year in gym class and she's just really nice with me; we had some activities together, and then she really helped me improve my English ... She was the first reason to me to love English, and love the classes, and love the school ... I was doing everything she does. I was a shy new student. I didn't speak English. She gave me her phone and I just start(ed) translating. Like I couldn't speak full sentences. I had vocabulary. She improved my English. Like 75 percent my English (improved) because of her, and the rest because of EAL classes. (NB SP5)

Many of the students admitted they were shy when they first arrived at ECHS. They described being intimidated by the sheer size of the school, including how the large physical structure made it difficult for them to find friends outside their own cultural and linguistic groups. Many described their fears about how they sounded when they attempted to speak English with

Journal of Contemporary Issues in Education, 2019, 14(1), pp. 33-54.

ISSN 1718-4770 (c) Author(s), Creative Commons Attribution 4.0 (CC BY 4.0) licence http://ejournals.library.ualberta.ca/index.php/JCIE 
Canadian students outside of their English as an Additional Language (EAL) classes. One participant stopped speaking for a long time in an academic course he was in with Canadian students because he felt ridiculed by some of his peers:

I didn't really feel that much hurt, it was just my English, like you know somebody comes (and) talks to you and I try to say a word, I say it in a different way ... I didn't find it that funny, but they did. But I won't lie, I was a little bit depressed. (NB SPI)

Another student described how she was encouraged by her teacher to speak more in class and how that support eventually helped her grow her confidence in her English-speaking abilities in front of her Canadian peers:

In math class, I'm shy because I'm scared my English is bad. I'm afraid nobody understands me. Cause I'm talking, (and) nobody understands me. I try that with some people. With my teachers, I'm talking (and) they understand so much to me... I'm talking, I understand (I am making sense) to my teacher. When I talk to another person ... like that (student makes a facial gesture of incomprehension). Some people when you're talking English they say you're like that... Like uh... feel, feel (not good). I feel very good ... very nice, when I talk to somebody and they understand me in English. When you (do) no(t) understand me, I feel bad. (NB SP7)

Several students shared their strategies on how they attempted to make Canadian friends. One student suggested that moving slowly toward friendship with Canadian students was very important:

Like, if you are in same class with someone and you spoke with him, and then you will ask, like 'can I be your friend or something?' I do that because some Canadians, don't want to be your friend. It's important to ask, 'can I be your friend?' Because if you didn't ask them the question, maybe this (person) doesn't want to be your friend or something and you joke with (them) and (they) tell the office and will make a problem. (NB SP4)

Another student described her deliberate attempts at making friends with varying degrees of success both within her own cultural and language group and among Canadian English students. She said she did not wait for them to engage her; she went to them to create conversation.

\section{Theme 2 - Working Through Traumatic Experiences}

The findings revealed several new insights for our team about the lived experiences of refugee children. At times in the interviews, we were not prepared emotionally for some of the stories the students shared with us.

Students described their experiences in their Syrian homeland, as well as their experiences they had while on route to Canada through countries including Turkey, Lebanon, and Jordan. All seven students we interviewed were directly affected by the war in Syria. One student displayed wisdom beyond his years as he described the war torn society he had left in the Middle East. In this case, the student had to flee Iraq with his family. At that time, they escaped to Syria and later confronted war for a second time. Of Iraq, the student said, 
I remember I used to live on the top floor, and if you want some war surviving tips, that's not the best place to stay when there is a war happening the next block to you. You want to go down to the basement, right? My dad took us to the basement and gave us headphones so we wouldn't hear the guns. I think I've had it lucky. I was in the basement. Some people are out on the streets ... some children my age. I can assure you that they were in way unsafe places (than me). So, that's Iraq. After 2002, the whole country just basically start ... falling down. Like there's no government, no control, you just (do) not feel safe. You get that feeling when you walk in a place at night, like, I can't wait until I get home, or I can't wait to get to that place I know I'm going to be safe. For us in Iraq, I don't think people feel that way. Like the safety feeling is taken away. Few people in Canada would know that because (they've) never lost that feeling all the time. The suicide bombers, we had a lot of them.

Deeper into the conversation, the student wanted to ensure that the researcher clearly understood what he was describing by offering the following penultimate statement about his experiences with war:

Personally, people have seen worse than me. I've seen quite a bit, but I mean ... I can assure you that people have seen way worse than what I've seen. I've heard the gun...I've seen the gun shot and I've been shot at while walking. That's bad. If you want to look at (the) Middle East, even right now ... it's like a hunger game. Imagine it like that, a hunger game. Anytime, you can die. No safety guaranteed ... That's the conflicts that happened (in) Iraq and Syria ... just like a whole big piece of ... just a war. You don't even know who's right or who's wrong. (NB SPI)

For many of the students we interviewed, suffering and trauma continued even after they had left the war zone. Stewart (2017a) describes this as 'triple trauma'. That is, people experience and suffer from trauma prior to and during war, while escaping the war on route to a new destination, and finally, while settling into and adjusting to their new country. Our student participants described experiences of being displaced to countries (i.e. Turkey, Lebanon, or Jordan) where they were able to attend school, but they encountered several teachers who did not care for them or give them the attention they needed. One student said, "I went to Jordan ... the school was so bad because like the... Jordanese people, they said you can't stay, get out of my country" (NB SP4). Another student who worked instead of attending school in Turkey described how his employer had taken advantage of him and his family:

I find (living) hard in Turkey... I see here different, different things ... in Turkey the life is hard ... everything is expensive in Turkey.... My dad he is four months working (and) he don't get the money, ever. Four months working, he don't have money. The boss (said) 'go away I can't give you money.' I have a job in (making) dessert. Two months, I come to Canada I (will) have 200 lyra in Turkey. He (my boss) tell me you have too many (much) money'. He can't give to me money ... He tell me 'how you go to Canada? Canada (is) very expensive.' I told him, I don't pay money. Then I'm liar, he tell me I'm liar. Go away, go, go, go. I don't get you. I can't go to police because I'm small ... I'm ... I'm young. I can't go because I was 14, I was 14 years but you have (to be) 17, 18 you 
can work. Seventeen is problem, 18 is okay. I'm 14, I can't work or I'm working because uh... We have to pay money for food, for everything. (NB SP7)

\section{Theme 3 - Supportive Relationships With Educators Are Key for New Canadian Students}

The students described their ECHS teachers and classrooms as supportive, welcoming, and engaging. The teachers were empathetic to the educational, social, and mental health needs of students. One participant said, "Let's be honest here, it doesn't matter how successful I was if I didn't have a good back up when I got here (at ECHS). A lot of people helped me” (NB SPI). The data sample below illustrates that the students were thankful for the extra effort and support their ECHS teachers provided them.

Like when I am in his class, I feel... I don't want to go out of the class. It's interesting. He (the teacher) makes the class fun ... like we learn and joke together ... joke and laugh and we have fun with learning. Like not just sit and do it. We learn, but we're having fun. (NB SP2)

I like Canada, because... I know school is very good ... better school. I like the teachers because they're very good (at) talking with you. (They) don't scream or anything. (NB $S P 7)$

When I was in Syria, I liked it, but when I came here, I liked it more, because of my teacher... I like it because (of) my teacher. If you don't like the teacher, you will hate the subject. Like when I was in Jordan, or Syria, I like the school, but in the morning, I feel, uh, I want to stay home. But here (in ECHS) I wake up, I like to come to the school. It's different, even my little brother when he was in Jordan he hate(d) the school, but here he loves it. (NB SP2)

When pressed to go beyond her description of her teachers at ECHS, one student pointed her finger at the researcher as she explained:

Teachers are very nice (at ECHS). When you need help, you'll find them always beside you. When they feel that you (are) suffer(ing), they'll be more with you, and it's like encouraging more. They give lots of encouragement, and they're always with us, every step... Just (like) a child with his parents who help him to a point with every step, they're just like that. They're helping us go up the stairs. (NB SP5)

\section{Theme 4 - Addressing Initial Fear and Building Resilience}

Early in the study, many of the educators said that the intake process for new immigrant and refugee students was very complex and fragmented at ECHS (Hamm, Oulette \& Hamm, 2017). This motivated us to ask each student to reflect on their arrival at ECHS. All the students said they were overwhelmed and scared when they arrived and felt lost for several weeks at ECHS. Two students capture the reality of being lost on arrival:

As a newcomer student, I had that feeling when you first moved into a new country, a new school, a new everything... I sat in the cafeteria, had my lunch by myself. That was my first day. I still remember that, never will (I) forget that. (NB SP1) 
I was so scared ... and I feel like I am different, I will not learn the language, I can't talk with teacher. I was so scared. (NB SP2)

However, the students were resilient. When they were sharing the stories of their lives, their struggles the past three to four years, and how they were working to better themselves on readjustment in Canada and at ECHS, we were very inspired. When asked what Canada meant to her, another student pondered momentarily and then said,

I'm thinking I want to live a better life. In Lebanon I (did) not study for two years because I am a Syrian in Lebanon. In Canada, I want to study and I want (to) do many things... I can do many things here. I want to be a nurse in Canada. I like helping people. (NBSP2)

We asked students how, given the opportunity, they might support new Canadian students who might arrive at ECHS in the future. Two students shared their ideas below:

Like I would tell them don't be scared because you are in the safe place. (NB SP4)

I will tell them when I came to here, when I came to here I was ... I was afraid and shy and worried, but after that I find it easy. Don't be afraid. (NB SP2)

Once the students had adjusted in the school, learned the structures and rules guiding student behaviors, and understood their responsibilities for their learning, their anxieties subsided, and they felt more comfortable in the environment. One student who had been in Canada for several years recalled his early struggles as well as his successes. He told us that if he had the opportunity to mentor new students at ECHS who had experienced what he had, he would tell them:

Okay this might seem tough right now, but I know (you) can turn it around. Moving is an experience; you choose to be positive or negative. Regardless of how things go, you have the power, you have the control to turn it around. For me, I can see it's hard. With language I was getting lost, but I knew that I was like going to reach what I want to the point where I knew what I'm doing. So I went to the classes. It got easier. It might seem bad, but people do it ... When I walked in the school, I just didn't even understand ... I felt lost ... but something deep down inside me ... something in me (said) I have to do this ... I had to learn it. I have to get to the point where I understand what they are saying and follow the instructions. It's a hard thing ... when I talked to a classmate who is a Canadian, he's like, 'I can't imagine.' But a lot of people did it. (NB SP1)

The student also believed it was important to provide new Canadian students more time and support when they arrived. He described how it was important for the school leaders to organize sustainable teams of student leaders to be with the new Canadian students when they arrived, for as long as they required. Based on his own adjustments in the school when he had arrived from Syria a few years earlier, he described his involvement as a student leader who took initiative to make sure new Canadian students found their place at ECHS quickly. He said the role of the student leader who is helping the new Canadian students adjust has to go beyond first day or even first week welcoming. He argues that

Journal of Contemporary Issues in Education, 2019, 14(1), pp. 33-54. ISSN 1718-4770 (c) Author(s), Creative Commons Attribution 4.0 (CC BY 4.0) licence http://ejournals.library.ualberta.ca/index.php/JCIE 
The first person you're going to meet is going to make a huge impression for you ... Maybe you don't understand the language ... but it's nice to feel that you're welcomed, that you're adopted, like yes I'm good here, like the language is not that big of a barrier. That was my goal. So for me (when I lead new students), I will come with a smile. I'm trying to engage in conversation with them. It's more than just a tour. (NB SP1)

\section{Theme 5 - Appreciation and Gratitude}

All eight student participants were grateful to be safe at ECHS and in their new city and country. One student said,

When we left Syria, I thought it would be the end of my life. I was leaving my country, and my best friend just passed away and I was really sad. I thought this was the end. But then I found out (that) here is where my life just started. (NB SP5)

We asked students how much they knew about Canada before arriving here. Collectively, they shared that they knew very little. Prior to boarding the airplane to Canada, the students said that they and their families were informed about the Canadian climate and about the support that would greet them in their new country. Many students then discussed their journeys into the unknown, arriving in January and February (2016) - two of the coldest and darkest months in Canada. We asked the students about their overall experiences at ECHS since they arrived and how they felt about their re-adjustment, as well as about their new community and country. The data below illuminates the appreciation and gratitude that students felt.

All people dream to come to Canada, in Syria. All people, because Canada is good for study, better... better school. I am happy because I'm with Canadians. (NB SP7)

It's a better life. And better life is better place, better food, better safety, and of course better education. It's just basically ... a safe spot. Like, that's the main reason if you ask me or anyone that has been caught in a war zone country. (NB SPI)

Canada means ... too much. It's not little. Not everyone can get a chance to come to Canada, and if they do that means they are so lucky. I want to stay here. (NB SP5)

Several students spoke of the reception they received at the airport when they arrived in their new city. Though they had been informed that they would be met in Canada, one student said the welcome went beyond what she and her family believed they deserved. She described this lifechanging event for herself and her family in detail:

I think everything we expected, it was more. We expected to find our dreams, and everything here, and we came and it was more than what we expected. It's a really nice feeling when we came here and the people are caring about us and just want to help us, and in the airplane everyone was asking questions, and wanting to know but we didn't have English. I wish I had English to tell them how happy I am, like I wish I had English to tell our volunteer my feelings about Canada. I had really nice feelings; I was so happy, and like everything got better after I had a little English. I was starting to have more friends, and tell them about my experience and how I came to Canada, and they all ask

Journal of Contemporary Issues in Education, 2019, 14(1), pp. 33-54. 
real nice questions, and they all care about ... they care about us. In some countries, they don't care. (NB SP5)

In the next section, we will discuss the findings from the student data from this part of our inquiry.

\section{Discussion}

\section{Theme 1 - Educators Must Intentionally Work to Build Bridges Between Students}

All the students we interviewed were re-adjusting their lives to fit into what they perceived to be the academic and social realities of ECHS and their new community. Six of the students seemed genuinely happy during their interviews with us and in our interactions with them afterwards when we saw them in the hallways on return visits. They were excited to be students again in a safe school, and they expressed a desire to remain in Canada for the duration of their lives. However, we identified one participant who was struggling with her re-adjustment in ECHS. During her interview, the participant suggested that she would return to her home country if she could. She described situations of struggle in one class and with some Canadian students. Some students had made her feel uncomfortable with their glances toward her. Researchers in Canada have identified realities of marginalization that many minority new Canadian students experience in their educations due to problems they encounter with students from the dominant cultures and populations (Goddard, 2007; Gunderson, 2000; Phan, 2003; Varma-Joshi, Baker \& Tanaka, 2004). Often, this marginalization can be subtle, even unnoticeable for educators to pick up on and confront educationally. The covert actions of some students can make new minority students feel unwelcome through their "controlling gazes" (Kelly, 1998). In her research in Alberta, Kelly (1998) argued that the controlling gaze

allows individuals belonging to a dominant group to control social spaces and social interaction ... The gaze constrains as it removes the degree of autonomy that would allow free physical and social movement. The purpose of the gaze is that it should subdue those who receive it and make them wish to be invisible. (p. 101)

We strongly advise educators and policy-makers to pay close attention to such events, so students do not become alienated in the school and within their new community (Banks, 2017). Robertson (2005) warned that students who feel marginalized in their schooling experiences in Canada may become disinterested in their learning and become disengaged, eventually dropping out of school. She argued that,

Behind the stereotype of charming little newcomers absorbing a new language "like sponges" hides an increasingly common story of disillusionment, dropping out, underemployment, and ghettoization. Several studies peg the dropout rate for ESL students at $75 \%$, three times the rate of non-ESL students. As more provinces adopt single exit exams, the drop-out rate for this group is expected to increase, along with the risk of creating a perpetual immigrant underclass of low-wage or unemployed adults. Bitter reality and shattered dreams create fertile soil for social hostility. (Robertson, 2005, p. 411) 
Several students in our inquiry clearly stated their desires to have more Canadian friends. Many new Canadian students were asking their classroom teachers at ECHS to help them meet Canadian students. We were inspired when several teachers informed us how they were trying to connect the students with their Canadian peers by constructing role playing situations in their classrooms so the new Canadian students could practice how to initiate conversations with Canadian-born students. The teachers' intentional actions to help new Canadian students engage their Canadian peers is transformative and socially just (Ghosh \& Abdi, 2013; Lund, 2003; Shields, 2013). In times of rapid immigration, demographic change, and increasing diversity in New Brunswick and Canada, educators must become critically aware of the relationships that are forming in their buildings. But perhaps even more important is for educators and school leaders to be profoundly aware of the barriers that might be impeding relational contact between students from diverse backgrounds with students from the dominant populations. If, as some students perceived, their inability to makes friends was due to their shyness or their limited ability to communicate in English, we argue that there is an enormous professional learning opportunity for educators. It is imperative that teachers and educational leaders at ECHS consider additional ways to bridge Canadian students to their new Canadian student peers. We encourage all Canadian educators to do this.

There is much that can be learned collectively in a diverse school by intentionally bringing young students together from different linguistic, cultural, racial, and religious backgrounds to share their stories and learn about each other, and we encourage teachers to do this. What is required is willingness on the part of educators to do this in their courses and through extracurricular activities in the school. The absence of a common language between students can no longer be perceived as a barrier that separates students. What we mean is that language barriers cannot exist in any Canadian context as the default to not trying to bring kids together.

\section{Theme 2 - Become Trauma-Informed to Respond Effectively to the Needs of Refugee Students}

We were cognizant that we were interviewing children who had fled war, had suffered educationally, socially, and emotionally to various degrees in another country, and then were elated to be leaving for New Brunswick, Canada - an unknown place. While working with students with trauma, Stewart (2017b) reminds educators to

Take the time to learn about where your students come from and acknowledge their past. Be open to hearing their personal story, but remember that behind the trauma story is the story of survival. See students with an "asset perspective" instead of a "deficit perspective." Help reorient students to focus on the skills, resources and power that they have to get them through difficult times. View each student who comes to school as having unique experiences and backgrounds that are worthy of celebrating. (pp. 23-24)

Stewart encourages educators to know the signs of stress and anxiety that students may be exhibiting and know who can help them if the educator is unable to at that time. Working with children and families who have endured war and trauma can be extremely difficult and challenging. Further, Stewart encourages teachers to "know your personal signs of stress and distress and know when, and how, to look after your own mental health" (2017b, p. 25). We also

Journal of Contemporary Issues in Education, 2019, 14(1), pp. 33-54. 
encourage educators who are working in diverse Canadian schools to be mindful of their own mental and physical health and to take care of themselves.

\section{Theme 3 - Relationships with Teachers Are Key for Refugee Students}

Overwhelmingly, students told us how important their teachers were in helping them develop their academic and social lives at ECHS. Many students who had fled war zones described in detail how their educations had been seriously disrupted. Researchers across North America have similarly described the significance of the relationships between new immigrant and refugee students with their teachers (Coelho, 1998; Derwing, 2003; Kirova, 2001; McDonald, 2000; Smith-Davis, 2004). One of the first human contacts that many new Canadian students have when they enroll in a school is with their English as an Additional Language teachers, if this service is resourced and available to them.

The narratives of many new Canadian students may astonish educators and leaders and "listeners may assume that survivors' stories are far beyond most people's experiences" (McDonald, 2000, p. 692). It is critically important that school leaders and educators continue to advocate for more professional learning on diversity and topics related to war and immigration that will help them understand the experiences of many refugee students. It is also important for educators to create learning opportunities and safe spaces in their classrooms for students to share their stories when they are ready. By doing this, educators help the students become "empowered to make life choices that are transformative in both their individual and social possibilities" (Ghosh \& Abdi, 2013, p. 49). The relational context between new Canadian students, their Canadian peers, and their teachers will provide the best opportunity for new Canadian students to flourish in their classrooms.

\section{Theme 4 - Create an Environment That Will Help Refugee Students be Resilient}

We were inspired with the stories of resilience and hope that the students shared. All the students arrived when New Brunswick had eight feet of snow on the ground. Several students had never been encouraged to learn English, and within a year, they were being interviewed by us. Their early fears slowly dissipated as they came to understand their school, the guidelines supporting their learning and behaviors, and where they perceived themselves to be able to thrive at ECHS. It is clear that new Canadian students need time and opportunities to re-adjust to their new realities. It must be a longer and sustained effort on the part of educators and support staff to help the new Canadian students. This is particularly important for students who have been out of school for a long time due to war and displacement and need to realign themselves with their learning abilities.

All the students we interviewed were ambitious and motivated in their learning. Many described how they were excited to be in a school where they could see pathways to opportunities in their lives. Students talked about becoming nurses, civil engineers, and business people. We learned from their teachers that many new Canadian students were taking leadership roles in the school. One participant was supporting new Canadian students who had arrived after him and even coordinating extra-curricular activities for the entire student body. If school leaders and educators continue to support students in growing their leadership capacities, they will create 
opportunities for all students to engage each other. The school will then have the best chance to grow and sustain a diversity-oriented leadership culture (Egbo, 2009).

\section{Theme 5 - The Students are Grateful}

The participants have a deep gratitude and appreciation for their teachers, the school leaders, their community, and their new country. The students we interviewed loved their teachers.

Certainly, the students described how they were missing their homelands and the family members who were still there, but they were grateful to be safe and for the support they were receiving at ECHS and in the community.

Educators do not always realize how their students, their parents, and the public are viewing their work in a world that Shields (2013) describes as volatile, uncertain, complex, and ambiguous. One student's story may help the educators in ECHS work through their doubt, and at the same time help the public understand that the equity-oriented, socially just, and transformative work the educators are doing is having a direct impact on new Canadian student lives. When we were interviewing one student and we asked about a teacher who had helped her, she began to cry and had to leave the room for a few minutes. When she returned to the interview, the researchers had learned that her family might have to move to another province to find employment. As researchers, we found this to be a common theme among our student participants. The work that teachers and school leaders are doing at ECHS is highly valued by the new Canadian students.

\section{Recommendations for Practice}

There is a growing body of literature in North America and Canada that advocates for educators, counselors, educational psychologists, and administrators to become more aware of demographic changes in their communities and schools (Evans, 2007; Hamm, Doğurga, \& Scott, 2016; Merchant, 2000). By increasing their global awareness and capacities to work with new immigrant, refugee, and international students and their families, educators can respond more effectively to the complexities they will encounter related to the increasing diversity in their schools. At the same time, they will be able to support and empower their new Canadian students during the entry phase and in their academic and social adjustments in their schools (Diem, Welton, Frankenberg \& Jellison Holme, 2016; Ghosh \& Abdi, 2013). "Paulo Freire (2000[1970]) has emphasized that people are never powerless" (as cited in Ghosh \& Abdi, 2013, p. 73) and we observed how new Canadian students had strengths and were resilient as they re-adjusted to their new lives in Canada. The socially just approach their teachers have taken with them is helping them shape their futures.

The student participants in our study want three things. They want to feel safe, they want to belong, and they want to build authentic relationships with their teachers and Canadian peers. Essentially, they want better lives. Several of the students were successful at the time we spoke to them; several participants still struggled, along with many other refugee students who did not volunteer to be interviewed, we learned. We have provided several suggestions through our discussion above, but it is imperative to make one more. New Brunswick and Canadian teachers, please prepare yourselves to teach and serve a diverse student body now and in the future. And if your classrooms are not culturally, linguistically, religiously, and racially diverse, we encourage

Journal of Contemporary Issues in Education, 2019, 14(1), pp. 33-54.

ISSN 1718-4770 (c) Author(s), Creative Commons Attribution 4.0 (CC BY 4.0) licence http://ejournals.library.ualberta.ca/index.php/JCIE 
you to be mindful that you are preparing students for a diverse world. Our children will be part of diverse communities wherever they go - whether in person or online. They need their teachers to prepare them so they may be positioned much better to understand this very complex world.

\section{Acknowledgements}

Our project was reviewed by the University of New Brunswick Research Ethics Board in December, 2014 (REB UNB File \# 2014-136), the New Brunswick Education and Early Childhood Development (EECD) in February, 2015, and by the School District where we conducted our research in March, 2015. We would like to thank the University of New Brunswick, the Harrison McCain Foundation, and the Center for Teaching and Learning at the University of New Brunswick for their financial support for our project.

\section{References}

Arnett, K. (2014). Stakeholders' inquiries about the systemic inclusion of late adolescent newcomers to Canada: Moving from questions to understandings. Learning Landscapes, $7(2), 41-58$.

Baddoura, C., \& Merhi, M. (2015). PTSD among children and adolescents in the Arab world. Arab Journal of Psychiatry, 26, 129-136.

Banks, J. (2017). Failed citizenship and transformative civic education. Educational Researcher, 46(7), 366-377. http://dx.doi.org/10.3102/0013189X17726741

Banks, J. A., Cochran-Smith, M., Moll, L., Richert, A., Zeichnerk, K., LePage, P., et al. (2005). Teaching diverse learners. In L. Darling-Hammond \& J. Bransford (Eds.), Preparing teachers for a changing world: What teachers should learn and be able to do, pp. 232271. San Francisco: Jossey Bass.

Bascaramurty, D. (2017, November 2). Canada aims for immigration boost to buttress economy: Open-door policy would bring in 340,000 permanent residents in 2020, even as U.S. mulls tighter borders. The Globe and Mail, A1, A4.

Beiser, M., Turner, R. J., \& Ganesan, S. (1989). Catastrophic stress and factors affecting its consequences among Southeast Asian refugees. Social Science \& Medicine, 28, $183-$ 195. http://dx.doi.org/10.1016/ 0277-9536(89)90261-X

Bissett, K. (2017, August 25). Refugees caused target miss, but that's OK: Gallant. The Daily Gleaner, A1.

Blanch, V. (2017, October 19). "Why don't you go back home?”: Rivalry fuels racism at high school football game: Stands at Moncton football game erupts with racial slurs, swearing and water bottles thrown at Syrian students. CBC Online News. Retrieved from http://www.cbc.ca/news/canada/new-brunswick/racism-moncton-high-riverviewfootball-syria-newcomers- 1.4358217

Bolgatz, J. (2005). Talking race in the classroom. New York: Teachers College Press.

Boswall K., \& Al Akash, R. (2015). Personal perspectives of protracted displacement: An ethnographic insight into the isolation and coping mechanisms of Syrian women and girls living as urban refugees in northern Jordan. Intervention, 13, 203-215. http://dx.doi.org/10.1097/WTF.0000000000000097

Journal of Contemporary Issues in Education, 2019, 14(1), pp. 33-54.

ISSN 1718-4770 (c) Author(s), Creative Commons Attribution 4.0 (CC BY 4.0) licence http://ejournals.library.ualberta.ca/index.php/JCIE 
Chilibeck, J. (2018, February 21). Feds unveil plan to boost immigration: "Study and stay" program, already underway in N.S. will expand across region. The Daily Gleaner, A1A2.

Coelho, E. (1998). Teaching and learning in multicultural schools. Clevedon: Multilingual Matters.

Cooper, C. (2009). Performing cultural work in demographically changing schools: Implications for expanding transformative leadership frameworks. Educational Administration Quarterly, 45(5), 694-724. http://dx.doi.org/10.1177/0013161X09341639

Delpit, L. (2006). Other people's children: Cultural conflict in the classroom. New York: The New Press.

Derwing, T. M. (2003). What do ESL students say about their accents? The Canadian Modern Language Review, 59(4), 547-566.

Diem, S., Welton, A., Frankenberg, E. \& Jellison Holme, J. (2016). Racial diversity in the suburbs: How race-neutral responses to demographic change perpetuate inequity in suburban school districts. Race, Ethnicity \& Education, 19(4), 731-762.

http://dx.doi.org/10.1080/13613324.2014.946485

Egbo, B. (2009). Teaching for diversity in Canadian schools. Toronto: Pearson.

Evans, A. (2007). School leaders and their sensemaking about race and demographic change. Educational Administration Quarterly, 43(2), 159-188. http://dx.doi.org/10.1177/0013161X06294575

Fram, S. (2013). The constant comparative analysis method outside of grounded theory. The Qualitative Report, 18(1), 1-25. http://www.nova.edu/ssss/QR/QR18/fram1.pdf

Gay, G. (2010). Culturally responsive teaching: Theory, research, and practice $2^{\text {nd }}$ edition. New York: Teachers College Press.

Ghosh, R., \& Abdi, A. (2013). Education and the politics of difference: Select Canadian perspectives ( $2^{\text {nd }}$ edition). Toronto: Canadian Scholars' Press.

Ghumman, U., McCord, C. E., \& Chang, J. E. (2016). Posttraumatic stress disorder in Syrian refugees: A review. Canadian Psychology, 57, 246- 253. http://dx.doi.org/10.1037/cap0000069

Goddard, J. T. (2007, May). Marginalization as international phenomenon: The alienation and lack of academic success experienced by indigenous and minority students within mainstream school systems. Paper presented at the Canadian Association for the Study of Educational Administration, Saskatoon, SK.

Gourley, J. (2016). If immigration is key to our economic future, should we still be saying "come-from-away"? Saltscapes 17(1), 47-49.

Government of Canada. (2018, February 28). \#WelcomeRefugees: Key figures. Retrieved from: https://www.canada.ca/en/immigration-refugees-citizenship/services/refugees/welcomesyrian-refugees/key-figures.html

Grady, K. (2001). "School made me stupid": The literacies and learning of immigrant adolescents in a Midwestern high school (Unpublished doctoral dissertation). Indiana University.

Gunderson, L. (2000). Voices of the teenage diasporas. Journal of Adolescent \& Adult Literacy, 43(8), 692-706.

Guterres, A. (2015, September 26). Canada, you're needed. Help more Syrians start a new life. The Globe and Mail, A18.

Journal of Contemporary Issues in Education, 2019, 14(1), pp. 33-54.

ISSN 1718-4770 (c) Author(s), Creative Commons Attribution 4.0 (CC BY 4.0) licence

http://ejournals.library.ualberta.ca/index.php/JCIE 
Hadfield, K., Ostrowski, A., \& Ungar, M. (2017). What can we expect of the mental health and well-being of Syrian refugee children and adolescents in Canada? Canadian Psychology/Psychologie canadienne, 58(2), 194-201. http://dx.doi.org/10.1037/cap0000102

Hamm, L., \& Cormier, K. (2015). School leaders face complex issues in diverse schools and communities. Antistasis, 5(1), 41-44.

Hamm, L., Scott, A., \& Massfeller, H. (2015). "They wanted to study us; they didn't want to help us": The impact and implications of immigration and demographic changes on teachers, administrators, students and community members in New Brunswick and Alberta. Paper presented at the Global Education: Common Wealth and Uncommon Citizenships Conference, Centre for Global Citizenship Education and Research (CGCER), University of Alberta, November 7, 2015, Edmonton, AB.

Hamm, L., Doğurga, S., \& Scott, A. (2016). Leading a diverse school during times of demographic change in rural Canada: Reflection, action and suggestions for practice. International Journal of Citizenship, Teaching \& Learning, 11(2), 211-230. http://dx.doi.org/10.1386/ctl.11.2.211_1

Hamm, L., Oulette, K., \& Hamm, L. A. (2017, February). The impact and implications of immigration, demographic changes and increasing diversity on teachers, administrators and students in a New Brunswick high school context. Unpublished pending summative report on Case Study 1 disseminated to study participants, school district leaders and the New Brunswick Education and Early Childhood Development (EECD).

Hamm, L., Massfeller, H., Hamm, L.A., Oulette, K., \& Damoah, D. (2017, December). Innocence Unfiltered - New Canadian refugee and new immigrant student re-adjustment in New Brunswick: The impact and implications of immigration, demographic changes and increasing diversity on teachers, administrators and students in a New Brunswick high school context. Unpublished Final Report on Case Study 1 disseminated to study participants, school district leaders and the New Brunswick Education and Early Childhood Development (EECD).

Hamm, L., Peck, C. L., \& Sears, A. (in press). Building inclusive schools and communities in New Brunswick: Choice of language matters in diverse communities. In D. Jahr und R. Kruschel (Eds.). Inklusion in Kanada-Perspektiven auf Kulturen, Strukturen und Praktiken (Arbeitstitel) [Inclusion in Canada-Perspectives on Cultures, Structures and Practices]. Weinheim, Germany: Beltz Publishers.

Hamm, L., Peck, C. L., \& Sears, A. (2018). "Don't even think about bringing that to school": New Brunswick students' understandings of ethnic diversity. Education, Citizenship and Social Justice, 13(2), 101-119. http://journals.sagepub.com/doi/pdf/10.1177/1746197917699219

Hassan, G., Ventevogel, P., Jefee-Bahloul, H., Barkil-Oteo, A., \& Kirmayer, L. (2016). Mental health and psychosocial wellbeing of Syrians affected by armed conflict. Epidemiology and Psychiatric Sciences, 25(2), 129-141. doi:10.1017/S2045796016000044

Henley, J., \& Robinson, J. (2011). Mental health issues among refugee children and adolescents. Clinical Psychologist, 15, 51-62. http://dx.doi .org/10.1111/j.1742-9552.2011.00024.x Howard, G. (2007). As diversity grows, so must we. Educational Leadership, 64(6), 16-22. Huras, A. (2016, October 15). 4 in 5 refugees from Syria in province are unemployed. The Daily Gleaner, A1-A2.

Journal of Contemporary Issues in Education, 2019, 14(1), pp. 33-54. ISSN 1718-4770 (c) Author(s), Creative Commons Attribution 4.0 (CC BY 4.0) licence http://ejournals.library.ualberta.ca/index.php/JCIE 
Kelly, J. (1998). "Experiences with the white man": Black student narratives. Canadian Ethnic Studies, 30(2), 95-113.

Kincheloe, J. (2005). Critical Pedagogy. New York: Peter Lang.

Kirova, A. (2001). Loneliness in immigrant children: Implications for classroom practice. Childhood Education, 260-267. http://dx.doi.org/10.1080/00094056.2001.10521648

Llewellyn, S. (2015, December 1). 300 to 600 refugees expected to resettle in city: Capital is translating newcomers guide, recreation guide and transit brochures into Arabic. The Daily Gleaner, A1-A2.

Lund, D. (2003). Educating for social justice: Making sense of multicultural and antiracist theory and practice with Canadian teacher activists. Intercultural Education, 14(1), 3-16. http://dx.doi.org/10.1080/1467598032000044610

McCray, C. R., Wright, J. V., \& Beachum, F. D. (2004). An analysis of secondary school principals' perceptions of multicultural education. Education, 125(1), 111-120.

McDonald, S. (2000). A touch of...class! Trauma and second language learning. The Canadian Modern Language Review, 56(4), 690-696.

Merchant, B. (2000). Education and changing demographics. In B. Jones (Ed.), Educational leadership: Policy dimensions in the 21st century. Stamford: Ablex Publishing.

Montgomery, E., \& Foldspang, A. (2005). Seeking asylum in Denmark: Refugee children's mental health and exposure to violence. European Journal of Public Health, 15, $233-$ 237. http://dx.doi.org/10.1093/ eurpub/cki059

Moussa I. (2014). Identity crisis in the Syrian society during the crisis. Thesis for Executive Master in Psychosocial Support \& Dialogue. IOM and Lebanese, University Beirut.

New Brunswick Government. (2014). New Brunswick Population Growth Strategy 2014-2017: Putting our resources to work. Retrieved from http://www2.gnb.ca/content/dam/gnb/Departments/petlepft/PDF/PopGrowth/PopulationGrowthStrategy2014-17.pdf

New Brunswick Government. (2016). New Brunswick’s Economic Growth Plan: Why growth is Imperative. Retrieved from

http://www2.gnb.ca/content/gnb/en/corporate/promo/EconomicGrowthPlan2016.html

New Brunswick Multicultural Council. (2016, November 17). Growing together: How communities can make it happen. Annual Symposium, Moncton, New Brunswick.

Pardhan, A. (1998). Silent voices of immigrant students. Alberta English, winter, 29-41.

Peck, C., Sears, A., \& Donaldson, S. (2008). Unreached and unreachable: Curriculum standards and children's understanding of ethnic diversity in Canada. Curriculum Inquiry, 38(1), 63-92.

Perreaux, L. (2017, November 4). After the Syrian initiative, UN looks to Canada as a refugee haven. The Globe and Mail, Retrieved from https://www.theglobeandmail.com/news/politics/after-syria-initiative-un-looks-tocanada-as-a-refugee-haven/article36836631/

Phan, T. (2003). Life in school: Narratives of resiliency among Vietnamese-Canadian youths. Adolescence, 38, 555-566.

Porter, G.L, \& AuCoin, A. (2012). Strengthening inclusion, Strengthening schools: Report of the review of inclusive education programs and practices in New Brunswick schools: An active plan for growth. Fredericton, NB: Government of New Brunswick. 
Pryor, C. (2001). New immigrants and refugees in American schools: Multiple voices.

Childhood Education, annual theme, 275-283.

Robertson, H. (2005). Lost in translation. Phi Delta Kappan, 410-411.

http://dx.doi.org/10.1177/003172170508600516

Rousseau, C., Drapeau, A., \& Rahimi, S. (2003). The complexity of trauma response: A 4-year follow-up of adolescent Cambodian refugees. Child Abuse \& Neglect, 27, 1277-1290. http://dx.doi.org/10.1016/j.chiabu .2003.07.001

Ryan, J. (2003). Leading diverse schools. Dordrecht, NL: Kluwer Academic Press.

Sather, S., \& Henze, R. (2001, Spring). Building relationships. National Staff Development Council, 28-31.

Shields, C.M. (2003). Good intentions are not enough: Transformative leadership for communities of difference. Lanham: Scarecrow Press.

Shields, C. M. (2013). Transformative leadership in education: Equitable changes in an uncertain and complex world. New York, NY: Routledge.

Sirin, S. R., \& Rogers-Sirin, L. (2015). The educational and mental health needs of Syrian refugee children. Washington, DC: Migration Policy Institute.

Skidmore, J. (2016). From discord to harmony: How Canadian music educators can support young Syrian refugees through culturally responsive teaching. The Canadian Music Educator, 57(3), 7-14. Retrieved from https://login.proxy.hil.unb.ca/login?url=https://search- proquestcom.proxy.hil.unb.ca/docview/1809639595?accountid=14611

Smith-Davis, J. (2004). The new immigrant students need more that ESL. The Education Digest, 69(8), 21-26.

Solomon, P., Levine-Rasky, C., \& Singer, J. (2003). Teaching for equity and diversity: Research to Practice. Toronto: Canadian Scholars' Press.

Soukamneuth, S. (2004, January). A climate for learning. Principal Leadership, 4(5), 14-19.

Stake, R. (1995). The art of case study research. Thousand Oaks: Sage.

Stake, R. (2000). Case studies. In N. Denzin \& Y. Lincoln (Eds.), Handbook of qualitative research (2nd ed.) (pp. 435-454). Thousand Oaks: Sage.

Stewart, J. (2017a, February 16). Mind the gap: Inequality, inequity and indifference.

Presentation at the New Brunswick Multicultural Council Conference: Building Bridges. Fredericton, New Brunswick.

Stewart, J. (2017b). A culture of care and compassion for refugee students. Education Canada, $57(1), 20-25$.

Ungar, M. (2013). Resilience, trauma, context, and culture. Trauma, Violence, \& Abuse, 14, 255-266. http://dx.doi.org/10.1177/15248380 13487805

Varma-Joshi, M., Baker, C., \& Tanaka, C. (2004). Names will never hurt me. Harvard Educational Review, 74(2), 175-208. http://dx.doi.org/10.17763/haer.74.2.p077712755767067

Vega, D., Lasser, J. \& Plotts, C. (2015). Global migration: The need for culturally competent school psychologists. School Psychology International, 36(4), 358-374. DOI: 10.1177/0143034315587011

Walker, A., \& Dimmock, C. (2005). Leading the multiethnic school: Research evidence on successful practice. The Educational Forum, 69(3), 291-304.

http://dx.doi.org/10.1080/00131720508984697

Journal of Contemporary Issues in Education, 2019, 14(1), pp. 33-54.

ISSN 1718-4770 (c) Author(s), Creative Commons Attribution 4.0 (CC BY 4.0) licence

http://ejournals.library.ualberta.ca/index.php/JCIE 
Wilson-Forsberg, S. (2012). “Getting used to the quiet:" Immigrant adolescents' journey to belonging in New Brunswick, Canada. Montreal-Kingston: McGill-Queen's University Press.

Wilson-Forsberg, S. (2016, October 6). Just trying to fit in: The settlement and integration experiences of youth from migrant families. Public lecture for the Gregg Center, University of New Brunswick, Fredericton, NB.

Journal of Contemporary Issues in Education, 2019, 14(1), pp. 33-54.

ISSN 1718-4770 (c) Author(s), Creative Commons Attribution 4.0 (CC BY 4.0) licence http://ejournals.library.ualberta.ca/index.php/JCIE 